\title{
Implementation of Rehabilitation Services in the National Narcotics Agency of South Sulawesi Province
}

\author{
Haerana \\ Public Administration, Muhammadiyah University of Makassar, Makassar, Indonesia
}

Email address:

Haerana@unismuh.ac.id

To cite this article:

Haerana. Implementation of Rehabilitation Services in the National Narcotics Agency of South Sulawesi Province. International Journal of European Studies. Vol. 3, No. 1, 2019, pp. 46-51. doi: 10.11648/j.jjes.20190301.18

Received: March 6, 2019; Accepted: April 13, 2019; Published: May 20, 2019

\begin{abstract}
In terms of quantity of drug users each year has increased significantly, the prevalence of drug abuse in South Sulawesi in 2008 amounted to $1.80 \%$ (103,849 people) and increased to $2.04 \%$ (121,773 people) in 2010 , even estimated to increase to $2.08 \%$ (125,730 people) by the end of 2011. The increasing trend of prevalence of drug users in Makassar every year continues to increase. Makassar City is still the highest city of drug users or about 33 percent of the total number of users in South Sulawesi Province. Therefore, more serious and systematic efforts to prevent and control drug users are needed. And the series of efforts can only be done well if supported by the efforts of the implementation of national policies and strategies for the prevention of drugs in the field of Rehabilitation organized by various government agencies and one of them is the National Narcotics Agency of South Sulawesi Province. This study aims to reveal how the implementation of drug rehabilitation services users. This research uses qualitative research method. Data collection was done in three ways, namely interview, observation and documentation study. The results of this study indicate that the implementation of rehabilitation services in the National Narcotics Agency of South Sulawesi Province has been running well although as many as 801 clients registered following the rehabilitation process, only 766 clients $(95.6 \%)$ declared successful completion of rehabilitation program (recovered), and as many as 35 clients did not complete the rehabilitation process due to leaving the rehabilitation institution.
\end{abstract}

Keywords: Policy Implementation, Rehabilitation Services, Drug Users

\section{Introduction}

In a joint survey of the National Narcotics Agency with the University of Indonesia's Center for Medical Research in 2008, drug abuse in Indonesia showed an upward trend and there was no sign of abating. The rise of drug circulation in Indonesia can not be separated from the foreign drug mafia who are very interested to make the network in Indonesia because of the economic potential of Indonesian society is getting better, of course the condition is very worrying because it will damage the quality of life of Indonesian people in general from various circles. Narcotics are substances or drugs derived from plants or non-plants, both synthetic and semi-synthetic. The substance causes decreased or altered consciousness, relieves the taste, reduces to relieve pain, and can cause dependence (addictive).

Final Report Results 2014 National Narcotics Agency states the social and economic impact of trade and drug abuse is very worrying about the world, including in Indonesia. Socio-economic losses due to drug abuse tend to increase from year to year.

The prevalence rate of national drug abusers by age 10-59 years is $1.99 \%$ of the population of Indonesia (3.6 million people) and in 2015 will increase to $2.8 \%$ (5.1 million people). While the prevalence rate of drug abuse in South Sulawesi in 2008 was $1.80 \%$ (103,849 people) and increased to $2.04 \%(121,773$ people) in 2010 , even estimated to increase to $2.08 \%$ ( 125,730 people) by the end of the year 2011. The increasing trend of prevalence of drug users in Makassar every year continues to increase. Makassar is still the highest city of drug users or about 33 percent of the total number of users in South Sulawesi.

At the regional level, data of 2015 from the National Narcotics Agency of South Sulawesi Province indicates that there are 125 thousand drug users in South Sulawesi. However, to date, only 620 people are undergoing 
rehabilitation. This fact also raises curiosity about the implementation of rehabilitation services at the National Narcotics Agency of South Sulawesi Province

\section{Literature Review}

National Narcotics Agency of West Java Province on its website describes about the negative effects of drug abuse both physical, psychological and social impacts (www.bnn.go.id) [7]:

1. Physically, in addition to damage to the nervous system as well as other organ functions, the spread of HIV / AIDS among injecting drug users can also occur.

2. Psychically someone who has used drugs will experience feelings of upset and depressed, feelings of insecurity, loss of confidence, often tense and anxious.

3. In addition there are also social effects of drug abuse, among others; anti-social, acting immoral, ostracized by the environment.

Ripley and Franklin explain that implementation is what happens after a law is established that gives program authority, policy, benefits, or a tangible output type. Implementation includes actions by some actors, especially bureaucrats, who are meant to make the program work [13].

Van Meter and Van Horn in Solichin [9], both of which restrict the implementation of policies as acts committed by individuals or groups of government or private aimed at achieving the objectives set out in policy decisions previous. These actions include attempts to convert decisions into operational actions over a period of time as well as in order to continue efforts to achieve the changes set by policy decisions. Dye [11] describe public policy as "Whatever governments choose to do or not to do", and according to Dunn [12], [Suwarno [10], the process of policy analysis is a series of activities in the process of political activities.

The process of public policy is a very complex activity carried out by those who sit at the level of political office. Charles O'Jones says, there are several stages that must be passed in the preparation of public policy namely definition/perception, Aggregation, organization, representation, arranging the agenda [3].

FormulationBased on the presentation of the psychological impact of drug use, Narcotics addicts and Narcotics abuse victims are required to undergo medical rehabilitation and social rehabilitation. (article 54 of Constitution No. 35/2009) on Narcotics. Rehabilitation is one of the efforts that can be done, because rehabilitation is a series of work or process of a job that aims to conduct rectification and improvement of the state of suffering more based on various disciplines that mutually support the improvement effort [4].

\section{Methodology}

The research approach used to answer the research question is qualitative by using case study type. The case study is a study of something 'unity of the system' in the form of programs, activities, events associated with specific places, times and bonds (Ghony and Almanshur), [2].

The technique to be used in determining primary data source or informant is purposive sampling through key person. Researchers will select informants with certain considerations. In this case people who act as formal or informal figures [1]. Researchers look for people who have the capacity and capability in accordance with the needs of research data. Determination of key informants is determined when entering the field and during the research or known by the emergent sampling design because the sample or informant in qualitative research can not be determined before [8].

Characteristic of qualitative research can not be separated from participant observation. In qualitative research the researcher participated as the main instrument [5]. The researcher is the planner, the data collector, analyzing the data, and interpreting the data and in the end he becomes the reporter of the research he has done.

And to preserve the objectivity of the researcher as an instrument, it used the points of the interview, the observation guide, and the documentation study guide as a guide asking questions, observations and documentation studies. Data analysis techniques used in this study is an activity that aims to process the data that has been obtained through interviews, observation and documentation study. The technique used is qualitative data analysis with the steps as follows:

1. Reduce Data

2. Presentation of Data

3. Verification and Withdrawal Conclusion

a. Trianggulasi

b. Member check

Result And Discussion

In the attachment of Presidential Instruction Of Indonesia no. 12 Year 2011 explained that the purpose of rehabilitation activities are as follows [6]:

Drug addicts who are old enough or their families and parents or Guardians of Narcotics addicts who are not yet old enough report themselves to the receiver institutions of compulsory reporting.

Gradually the abusers, abuse victims of drugs, and drug addicts can receive medical rehabilitation and social rehabilitation services.

Gradually the availability of medical rehabilitation and social rehabilitation institutions in areas prone to drug abuse.

The abusers, victims of narcotics abuse and drug addicts who have completed complete rehabilitation programs are continuing to follow "after care programs" to prevent relapsing.

A series of objectives of the Rehabilitation program as described above, it is clear that the series of activities are well structured for the recovery of physical and psychological conditions of drug abusers. And the national narcotics agency of south sulawesi province as one of the organizing institutions that will carry out the Presidential Instruction is obliged to ensure that the objectives of the rehabilitation program can be achieved well. 
According to Mr. Jamaluddin as Head of prevention and community empowerment of the national narcotics agency of south sulawesi province, he said that the tendency of increasing the number of narcotics abusers every year due to the rapid development of technology and information so as to facilitate the occurrence of transactions, so it can be ascertained currently there are abusers in every government and non-government institutions and at every level of education.

Paying attention to the number of prevalence that increased significantly then it should take special attention from various parties both from the government, private and community to provide support and help the success of any programs prevention and eradication of drug abusers in order to save the next generation of the nation.

Based on the results of the research from national narcotics agency of indonesia in collaboration with the Research and Development of the University of Indonesia in 2012, describes that the type of Narcotics that many abused in the worker's environment is the type of dektro (53.3\%), marijuana $(16 \%)$, shabu $(9.3 \%)$, dexa $9.3 \%)$ then extacy $(6.7 \%)$ and codein $(2.7 \%)$. In detail can be seen in the following of this chart:

Table 1. Projection of drugs abuser in south sulawesi by group of household, worker and student 2014-2019.

\begin{tabular}{lllllll}
\hline \multirow{2}{*}{ Group } & Year & & & & \\
& $\mathbf{2 0 1 4}$ & $\mathbf{2 0 1 5}$ & $\mathbf{2 0 1 6}$ & $\mathbf{2 0 1 7}$ & $\mathbf{2 0 1 8}$ \\
\hline Household & 5100 & 5100 & 5000 & 5000 & 4900 \\
Worker & 89400 & 91500 & 93600 & 95700 & 9900 \\
Student & 31100 & 31400 & 31800 & 32100 & 97800 & 32400 \\
\hline
\end{tabular}

Source: Litdatin BNN RI 2014.

Based on the projection data of drug abusers mentioned above, it can be seen that the quantity of groups of workers and students / students whose numbers have increased in each year. This is understandable because groups of workers and students have more interaction with the outside world and they are the largest social media users in the community.

Drug Abuse Rehabilitation is divided into two, namely Medical Rehabilitation and Social Rehabilitation. Medical Rehabilitation is an integrated process of therapeutic activity to free narcotic addicts from narcotics dependence. While Social Rehabilitation is a process of recovery activities in an integrated, both physical, mental and social, so that former drug addicts can re-implement social functions in public life.

Effectiveness of community empowerment in terms of encouraging the establishment of rehabilitation and postrehabilitation of community components in the province of South Sulawesi by 2015. Rehabilitation has implemented cooperation with 4 (four) Community Component Rehabilitation Institutions.

The rehabilitation field focuses on:

1. Efforts to intensify the Reporting Obligatory Narcotics Report.

2. Efforts to provide medical rehabilitation and social rehabilitation services to abusers, victims of abuse and drug addicts.

3. Efforts to build the capacity of medical rehabilitation institutions and social rehabilitation on a priority basis based on the vulnerability of drug abuse areas.

4. Further coaching efforts to former abusers, victims of abuse and drug addicts.

In Constitution No. 35 of 2009 on Narcotics in article 54 it is stated that Narcotics addicts and victims of Narcotics abuse must undergo medical rehabilitation and social rehabilitation. It is therefore clear that if there is a Drug Abuser as soon as possible concerned (if already an adult) or a parent of the abuser (if the offender is not old enough) immediately perform the reporting duty so that the abuse immediately undergoes medical rehabilitation and social rehabilitation. The surrounding community must initiate this compulsory reporting activity in order to reach the drug-free environment immediately.

The Narcotics Reporting Arrangement aims to fulfill the right of Narcotics addicts in obtaining treatment and or treatment through medical rehabilitation and social rehabilitation; involving parents, caregivers, families and communities in enhancing the responsibilities of Narcotics addicts under their supervision and guidance; and provide information materials for the government in establishing policies in the field of prevention and eradication of illicit abuse and illicit traffic.

Submission of Narcotics Report shall be conducted in the receiver institutions of compulsory reporting; Public health centers, hospitals and / or medical rehabilitation institutions as the Reporting Beneficiary Institution shall be established by the Minister of Health No. 1305 / MENKES / SK / VI / 2011 on the receiver institutions of compulsory reporting. In addition, the social rehabilitation institution as the receiver institutions of compulsory reporting is established by the Minister who administers government affairs in the social field.

From the implementation of data collection on the the receiver institutions of compulsory reporting which implemented by the National Narcotics Agency of South Sulawesi Province is known throughout 2015 the Service of receiver institutions of compulsory which has been given is 405 service people and the receiver institutions of compulsory reporting under the auspices of the Ministry of Health contributed 12 service at the Pare-Pare City public hospital. Against the South Sulawesi community who have received service from the receiver institutions of compulsory reporting, will be get the follow-up counseling in the form of outpatient rehabilitation was 226 people using try and rehabilitation of inpatient was conducted on 231 addicts or in other words the number of the receiver institutions of 
compulsory reporting services that have been implemented at the National Narcotics Agency of South Sulawesi in the region is as much 457 people.

Compared with performance targets on performance indicators The number of Drug Users reporting themselves to receiver institutions of compulsory reporting in fiscal year 2015 was 110 people, the achievement of the National Narcotics Agency of South Sulawesi Province performance in 2015 has exceeded the target set by the Head of the National Narcotics Agency with achievement of $415 \%$, thus it can be concluded that the implementation of the program to intensify the number of mandatory report in the National Narcotics Agency of South Sulawesi has been running well.

Distribution of drug abuser rehabilitation based on the type of service at receiver institutions of compulsory reporting in South Sulawesi region, total of targeted 740 inpatients, and $533(72.03 \%)$, and outpatient outreach as many as 1,615 people and realized as many as 434 people $(26.87 \%)$, while the case of legal rehabilitation conducted through Integrated Assessment Team was initially targeted only 74 people, but as many as 162 people $(218.92 \%)$ realized, meaning that there were over 88 people.

The following will explain some reasons why addicts and drug abusers should be in Rehabilitation:

If we say that the abusers and addicts are law breakers, that's true but they are not criminals, they are just victims of the coaxing of the dealers and bookies. Addictive properties contained in drugs, making the abuse and addiction addicts to consume drugs.

Continuous drug use affects a person's physical damage, is susceptible to illness and can damage the central nervous system causing them to become insane or mentally retarded and even cause death. Thus, it can be said that abuse and drug addicts are the sick people we must help and cure of dependence before the effects of drugs kill the function of his brain.

Talking about drugs means talking about supply and demand. The more (demand) demand means the drug will continue to exist or increase (supply). Rehabilitating drug abusers and addicts to recovery is a move to suppress demand. If there is no demand from the consumer, the dealer and the dealer will be out of business by themselves.

Based on the National Narcotics Agency of Indonesia research, every day 40-50 generations of Indonesian nation died of drugs. 1.2 million people can not be rehabilitated because of his condition is too severe. Steps to rehabilitate drug abusers and addicts are one of the steps that the Indonesian nation does not lose its generation back.

Drug abuser is declared recovered when successfully completing the rehabilitation process as planned by the assessment team. Throughout 2015, of the National Narcotics Agency of South Sulawesi Province has been referring 1,280 clients to undergo rehabilitation process at government institution rehabilitation institutions as many as 1,014 clients (79.21\%) and community component rehabilitation institutions as many as 266 clients $(20.78 \%)$.

Table 2. Percentage Recovery Of Inpatient Rehabilitation Service 2015.

\begin{tabular}{llllll}
\hline \multirow{2}{*}{ No } & Institution & $\begin{array}{l}\text { Total Of } \\
\text { Residents }\end{array}$ & Recovery & Done & Recover \\
\cline { 3 - 5 } & & 251 & 0 & 251 & 100.0 \\
2 & Baddoka & 47 & 18 & 29 & 61.7 \\
3 & SPN & 2 & 0 & 2 & 100 \\
4 & RINDAM & 38 & 7 & 31 & 81.6 \\
5 & DHAYANGKARA & 1 & 0 & 1 & 100.0 \\
6 & RSKO & 2 & 0 & 2 & 100.0 \\
7 & LAPAS/RUTAN & 193 & 0 & 193 & 85.0 \\
8 & YKP2N & 28 & 4 & 24 & 98.7 \\
9 & LPAB & 157 & 2 & 155 & 100.0 \\
10 & LP4 & 46 & 0 & 46 & 100.0 \\
11 & DOULOS & 7 & 0 & 7 & 100.00 \\
12 & LPAIC & 5 & 0 & 19 & 82.6 \\
13 & LASM & 23 & 4 & 1 & 100.0 \\
14 & YRRCB & 1 & 0 & 766 & 95.6 \\
Amount & & 801 & 35 & 5 & \\
\hline
\end{tabular}

Report: The National Narcotics Agency of South Sulawesi Province.

Based on table 2 above, there are 801 registered clients follow the rehabilitation process, only 766 clients (95.6\%) declared successful completion of the rehabilitation program (recovered), and as many as 35 clients who did not complete the rehabilitation process because leaving the rehabilitation institution.

Table 3. Percentage Recovery of Outpatient Rehabilitation Services Per Institution in South Sulawesi Year 2015.

\begin{tabular}{|c|c|c|c|c|c|c|c|c|c|c|}
\hline \multirow{2}{*}{ No } & \multirow{2}{*}{ Institution } & \multirow{2}{*}{$\begin{array}{l}\text { Total } \\
\text { Residents } \\
\end{array}$} & \multicolumn{8}{|c|}{ frequency of visits } \\
\hline & & & 1 & 2 & 3 & 4 & 5 & 6 & 7 & 8 \\
\hline 1 & KLINIK BNNP SULSEL & 369 & 39 & 47 & 34 & 24 & 14 & 11 & 7 & 193 \\
\hline 2 & KLINIK BNNP PALOPO & 27 & 13 & 3 & 1 & 1 & 1 & 0 & 0 & 8 \\
\hline 3 & KLINIK BNNK TATOR & 27 & 10 & 3 & 1 & 2 & 0 & 0 & 0 & 11 \\
\hline 4 & RSKD SULSEL & 7 & 0 & 0 & 0 & 0 & 0 & 0 & 0 & 7 \\
\hline 5 & RSU LAMADDUKELLENG & 2 & 0 & 0 & 0 & 0 & 0 & 0 & 0 & 2 \\
\hline
\end{tabular}




\begin{tabular}{|c|c|c|c|c|c|c|c|c|c|c|}
\hline \multirow{2}{*}{ No } & \multirow{2}{*}{ Institution } & \multirow{2}{*}{$\begin{array}{l}\text { Total } \\
\text { Residents }\end{array}$} & \multicolumn{8}{|c|}{ frequency of visits } \\
\hline & & & 1 & 2 & 3 & 4 & 5 & 6 & 7 & 8 \\
\hline 6 & RSU TENRIAWARU & 3 & 0 & 0 & 0 & 0 & 0 & 0 & 0 & 3 \\
\hline 7 & RSU NENEMALLOMO & 9 & 0 & 0 & 0 & 0 & 0 & 0 & 0 & 9 \\
\hline 8 & RSU ANDI MAKKASAU & 12 & 0 & 0 & 0 & 0 & 0 & 0 & 0 & 12 \\
\hline 9 & RSU BATARAGURU & 11 & 0 & 0 & 0 & 0 & 0 & 0 & 0 & 11 \\
\hline 10 & PUSKESMAS MAKKASAU & 5 & 0 & 0 & 0 & 0 & 0 & 0 & 0 & 5 \\
\hline 11 & PUSKESMAS ANDALAS & 5 & 0 & 0 & 0 & 0 & 0 & 0 & 0 & 5 \\
\hline \multirow[t]{2}{*}{12} & PUSKESMAS PANGKEP & 1 & 0 & 0 & 0 & 0 & 0 & 0 & 0 & 1 \\
\hline & Amount & 478 & 62 & 53 & 36 & 27 & 15 & 11 & 7 & 267 \\
\hline
\end{tabular}

Report: The National Narcotics Agency of South Sulawesi Province.

Based on table 3 above, it shows that outpatient rehabilitation services only reached $55.74 \%$, which is stated to be recovered (completing the outpatient rehabilitation process), the remaining $12.94 \%$ visited only once, $11.06 \%$ visited only 2 times, $7.52 \%$ visited only three times, $5.64 \%$ visited only four times, $3.13 \%$ visited only 5 times, 2.30 visited only 6 times, 1.46 visited only 7 times. Overall, the resident who completed the rehabilitation process both inpatient and outpatient in South Sulawesi region as many as 1033 clients $(80.70 \%)$.

Re-use means the client who has completed the rehabilitation and post-rehabilitation process, but the client re-uses the drug. Based on the client's family confirmation, as many as 15 clients who returned using drugs, it means there are still as many as $98.59 \%$ that can maintain the recovery.

The effectiveness and benefits of rehabilitation and postrehabilitation activities that have been conducted throughout 2015. The success indicators of the activities are when participants in rehabilitation and post-rehabilitation services have completed activities to realize the work plan and keep it in clean condition, for students who follow the program after completing the program can continue education at school or a former user who has recovered can do a new job that ditekuninya with dedicated.

\section{Conclusion}

Efforts of National Narcotics Agency of South Sulawesi Province in providing rehabilitation services to drug abusers has been done optimally. This is evident from the establishment of rehabilitation and post-rehabilitation institutions of the community in the province of South Sulawesi in 2015. The Rehabilitation field has implemented cooperation with 4 (four) Rehabilitation Institutions.

The percentage of recovery from clients following the rehabilitation process in South Sulawesi was $80.70 \%$ or exceeded the national success standard of $60 \%$. The percentage of clients who can maintain their recovery in South Sulawesi by the end of 2015 is $98.59 \%$ or exceeds the national standard of $40 \%$.

The obstacles faced by the National Narcotics Agency of South Sulawesi Province in carrying out Rehabilitation Services are as follows:

1. The lack of human resources in the field of rehabilitation.

2. Low quality of Human Resources for Rehabilitation.
3. The lack of budget allocation for rehabilitation in the regions.

4. Claims for rehabilitation services must be central, so it still raises the doubt of the officers in the region to be able to be creative in carrying out activities because of doubt can or can not claim the funds.

5. Understanding the community is still low, because the process of procurement billboards, banners, and leaflets for rehabilitation to rehabilitation institutions experienced delays.

\section{Acknowledgements}

The author would like to thank to the management institutions of education fund (LPDP) of Indonesia who has approved and provide fund support for my participation in this international conference and thanks also to Prof. Haedar Akib, M.Si as the chairman of committe in the doctoral program of the public administration science department for his assistance in completing this article.

\section{References}

[1] Bungin, M. Burhan, 2007, Qualitative Research: Communication, Economics, Public Policy and Other Social Sciences, Jakarta: Kencana.

[2] Ghony, M. D, dan Almanshur, F, 2012, Qualitativee Research Methods, Yogyakarta: Ar-Ruzz Media.

[3] Jones, Charles O. 1996. Introduction to Public Policy. Translate by Rick Ismanto. Jakarta: Publisher PT RajaGrafmdo Persada.

[4] Law of the Republic of Indonesia No. 35 of 2009 concerning Narcotics

[5] Moleong, L, J. 2009. Qualitative Research Methods. Bandung: Rosdakarya.

[6] Presidential Instruction No. 12 of 2011 concerning the Implementation of National Policies and Strategies for the Prevention and Eradication of Illegal Abuse and Circulation of Drugs

[7] Republic of Indonesia Government Regulation Number 25 of 2011 concerning Compulsory Implementation of Report on Narcotics Addicts.

[8] Sugiyono. 2009. Quantitative Research Methods, qualitative and R \& D. Bandung: Publisher Alfabeta. 
[9] Solichin, Wahab Abdul. 2008. Introduction to Public Policy Analysis. Malang, UMM Press.

[10] Suwarno, Yogi. 2008. Innovation in the Public Sector. Jakarta: STIA LAN Press

[11] Thomas R. Dye. 1978. The Political Economy Of Growth Policies in cities. Florida State University
[12] William N. Dunn, 2003. Introduction to Public Policy Analysis. Gadjah Mada University Press: Yogyakarta. Terjemahan, Hal. 24-25

[13] Winarno, Budi. 2007. Public Policy: Theory and Proses. Yogyakarta, Med Press. 